\title{
The Practice and Prospects of Accounting Information Systems (AIS)
}

\author{
Khalid A. Fakeeh, PhD \\ FCIT, King Abdullaziz University \\ Jeddah, Saudi Arabia
}

\begin{abstract}
The accumulation, storage and handling of budgetary and bookkeeping or accounting information/data that is utilized by leaders or decision makers. An Accounting Information System (AIS) is by and large a PC based system for following accounting activity in conjunction with data innovation assets. The subsequent factual reports can be utilized inside by administration or remotely by other invested individuals including financial specialists, banks and duty powers. We outline the present and prospect position of (AIS) by analyzing the key commitments of clerks (accountants) and cash related or finance specialists. While a couple of these commitments are starting now suitably reinforced by standard development answers, others address defies that still not have fitting clarifications and thusly ought to be the focal point of prospect investigation. We expect prospect creative reactions to this concern area defies. The recognized advances fuse business Process Management (BPM), Cloud computing, mobile phones, Big Data, Computer assisted tools and techniques, enterprise application integration, web services, business intelligence (BI) mobile computing (MC), environmental scanning.
\end{abstract}

\section{Keywords}

AIS, IS, MIS, ERP

\section{INTRODUCTION}

The AIS is by and large a Computer-based technique for tracking the goings-on of accounting in combination with IT resources [A. Fontinelle]. Accounting Information System is in charge of the accumulation, storage and handling of accounting and financial information that is utilized for inward administration choice making, comprising nonfinancial exchanges or transactions that specifically influence the preparing of monetary exchanges. Normally AIS is made out of following three noteworthy subsystems:

(i) (TPS): Transaction Processing System that backings day by day business operations.

(ii) (GLS/FRS): General Ledger System and Financial Reporting System.

(iii) (MRS) Management Reporting System [J. A. Hall].

Transaction Processing System is in charge of supporting day by day business operations or exchanges/transactions. These transactions can be gathered together in three exchange or transaction cycles such as (the income or revenue cycle, the cost or expenditure cycle and the transformation or conversion cycle). The motivation behind the first IS's been to automate business processes, which demonstrates that the area of accounting was one of the first to make use of IS's to bolster its exercises [A. Rom et al, 2007]. Without a doubt the period of computing accounting propelled with the presence of the first PCs, which got to be accessible for accounting exercise in late 1953 [A. Anandarajan et al]. Normally seen as a solitary coordinated service, the General Ledger System and Financial Reporting System are two firmly related frameworks, with the first devoted to synopsis of transaction cycle movement and the second one to the estimation and reporting of the status of monetary assets, for the most part yielded as tax returns or money related explanations [J. A. Hall, 2010]. Management Reporting System offers inner administration with exceptional reason budgetary reports and data required for choice making, for example, variance reports, budgets and obligation reports. The fundamental thought for all experts from accounting domain perspective regarding the IS of an association/organization and especially an AIS is grasped by the ERP, which includes all the vital capacities to bolster an association and is actualized in every cosmic organization or business group [J. Varajão et al, A. Trigo et al]. The [A. Rom et al, 2006] is moving far from this built up perspective about Accounting Information System area, considering now a more particular way to deal with an Accounting Information System where new innovations like Balanced Scorecard (BSC) or Business Intelligence (BI) frameworks assume an undeniably critical part [A. Rom et al 2007, S. V. Grabski et al 2011].

\section{ACCOUNTING DEFIES \& IT'S TECHNOLOGICAL ELUCIDATIONS}

An extensive online review was led by the Chartered Institute of Management Accountants (CIMA) and by the UK's University of Bath to 5,426 senior money and senior non-fund experts around the globe in June 2010 [W. Van der Stede et al 2010]. The respondents of this study were an extensive variety of monetary experts, from all areas of the world, with obligations divide into six classes (The accounting operations, which incorporates transactions handling, accounts payable and receivable, and inner budgetary reports, outside reporting, which incorporates legal reporting, business finance, capital and budgetary jeopardy, and regulation, comprising inside reviews, consistence with administrative prerequisites, and taxes; putting in an order and deciphering MIS, for example, estimating, planning, costing and variance reporting, and in addition flow management; management bolster, which incorporates distinguishing and breaking down key alternatives, choice bolster, outlining and following key faculty markers, benchmarking, vital management accounting, and business risk management; creating, executing and keeping up MIS and other like staff training, management and different incidental exercises. The above study demonstrated that the most recent most vital tendency in accounting experts is the movement of bookkeepers' obligations from conventional accounting operations to strategic management. This tendency, a result of the monetary emergency in 2008 , 
speaks to an increment of the quality added to the association and the commitment performed by bookkeepers or accountants. These days, real partnerships or business groups overall need experts who comprehend risk management, income, money related instruments and other complex capacities that can offer key direction to top administrators [W. Van der Stede et al 2010]. The outcomes additionally underscored the requirement for monetary experts stay consistent with the conventional obligations of bookkeeping/accounting operations. Reporting is likely the action most often performed by accountants. Accountants' should have the capacity to deliver reports continuously and intuitively permitting them to pick what to put in the reports, perform investigation and situation creation without the intercession of the Information Technology group. Besides, with the late global budgetary emergency, the utilization of Accounting Information System by outer partners is turning out to be more essential and exceptionally a great deal [W. Van der Stede et al 2010]. One action that is generally performed by accountants is Auditing, typically partitioned in two noteworthy categories: (i) Internal Auditing and (ii) External/Independent Auditing. Internal Auditing spreads an extensive variety of exercises in the interest of the association, including leading monetary articulation reviews, looking at an operation's consistence with hierarchical arrangements, assessing the association's consistence with legitimate commitments, assessing operational proficiency, recognizing and seeking after extortion inside of the firm, among others [J. A. Hall, 2010]. Internal Auditors need to bolster their exercises with the utilization of IT like Workflow Management Systems (WMS) [N. V. d. Almeida et al, 2012]. External Auditors' exercises are like those performed by the Internal one yet more centered around the particular laws or tenets on the money related articulations of an association and not on operational matters [J. L. Colbert]. External Auditors speak to outsider pariahs, though internal auditors serve the leading body of the association [J. A. Hall 2010, J. L. Colbert]. Review firms are ceaselessly performing so as to search for approaches to expand effectiveness centered review methodology and are progressively depending on compelling internal audit controls and divisions. Engagement groups are required to partake in conceptualizing gatherings to distinguish dangers coming about because of blunder or misrepresentation, alongside approaches to address these dangers. Therefore, audit firms are progressively swinging to Computer Assisted Auditing Tools and Techniques (CAATTs) [M. D. Mayberry]. If on one hand it shows up incredibly clear that the novel accountants' commitments like management support got from the 2008 economic crisis require fitting technological elucidations or solutions. Of course, a rate of the standard accountants' commitments continue presenting troubles and should not be released in a work that seems to be a thinking on the answers that progressions can accommodate the needs of the Accounting territory. In this way, in light of the composition overview coordinated, the most vital defies or apprehensions toward accounting are accounting operations, external reporting, management accounting, management support staff management, training, examination of capital exercises, highlight on customers and products, reports about debtor and creditor ageing, ceaseless or real-time reporting, keen/interactive reporting, auditing, internal controls use, risk management, misstep or coercion area etc [J. A. Hall, A. Rom et al, A. Anandarajan et al, M. D. Mayberry, R. B. Cooper, R. S. Poston et al, M. G. Alles et al, R. R. Moeller]. A couple of these accounting worries starting now benefit by standard technological replies, a huge part of them gave by Enterprise Resource Planning systems. The focal point is to identify the distress with difficulties that still don't have legitimate inventive clarifications and hence ought to be the focal point of future investigation like, external and consistence reporting, benchmarking, strategic examination, internal auditing, forecasting, internal controls, get to and report nonfinancial data, interactive reporting, analyze historical data, risk management.

\subsection{Technological Elucidations}

The course of action of commerce/trade and Information Technology is still a basic stress of both of these overseers. Endearing affiliations depend on upon the game plan of these two universes among its multifaceted estimations in terms of communications, competency/regard estimation, organization, association, creative expansion or capacities) [J. Luftman]. On account of its inconvenience and multifaceted nature, this errand decidedly desires unsullied standpoints to perform it, for event, regarding workforce rousing strengths $[\mathrm{F}$. Belfo 2013, F. P. Belfo 2011] or the role of knowledge management in this plan [F. Belfo 2010]. IT, particularly its support to accounting information system, has shown to have a constructive outcome on associations' execution and proficiency [E. U. Grande et al 2011]. In like way to [N. A. Ismail et al] the enthusiasm for accounting information system (AIS) by Small and Medium Enterprises (SME), develops the degree of action, extras time in trips to and dealings with banks, the central association, et cetera., growing association's gainfulness and diminishing association's outlays only if the headways are honest to goodness brought into play [N. A. Ismail et al]. The most vital current slants and defies around finance and accounting, independently associated with some technological ways that should give adequate reactions to those troubles has been portrayed in figure 1. But distinctive relations stay alive; the lines indicate majority the crucial ones. 

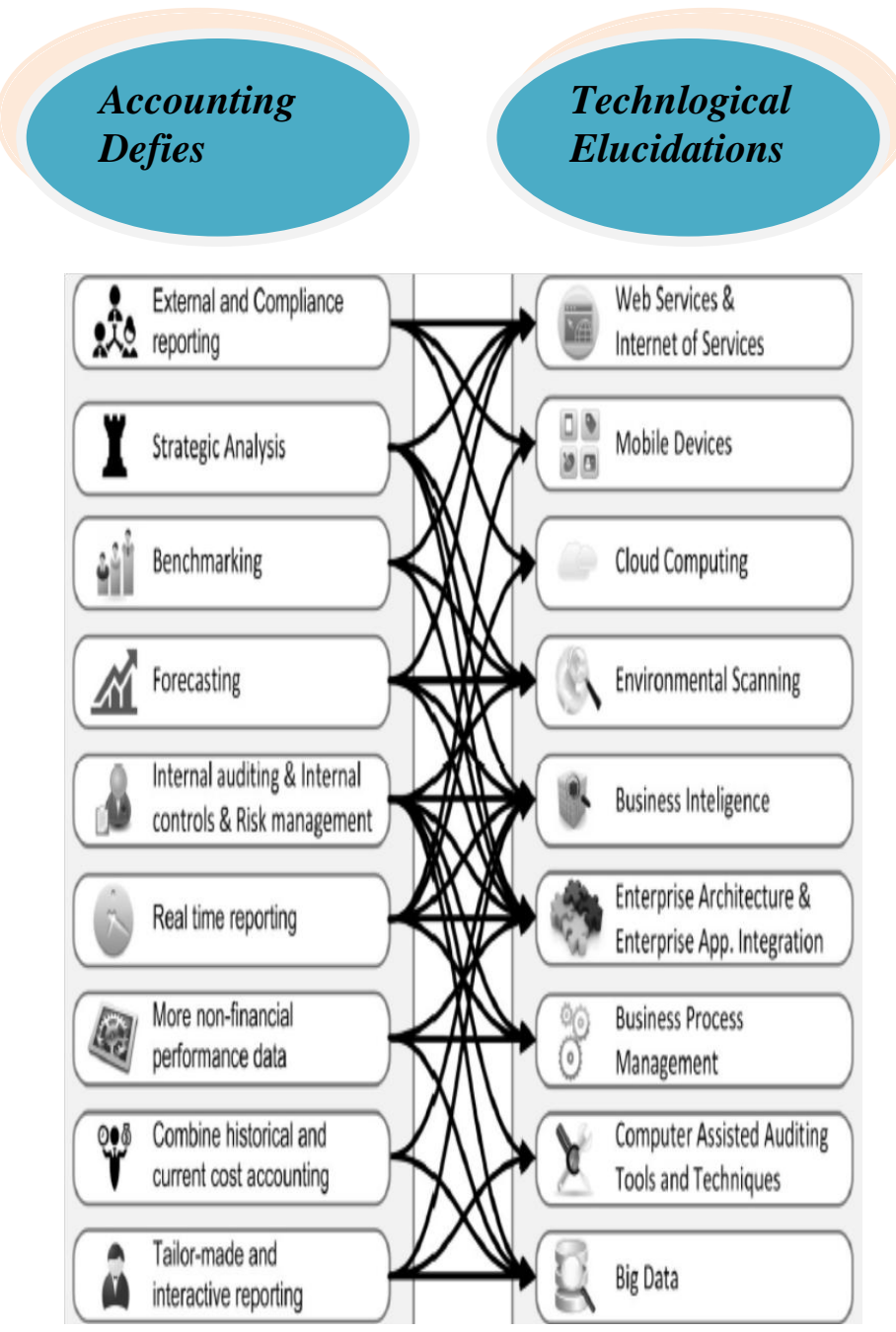

Figure 1: Accounting Defies and its Technological way out [Fernando Belfo et al, 2013]

\section{A. Internet of Services (IoE) \& Web Services}

The revelation of the Internet of Services (IoS) portrays an establishment that brings into play the Internet as a medium for bestowing and selling services which get the opportunity to be tradable stock [J. Cardoso et al]. Among distinctive services, web or online invoicing and online charging are regularly exercised by paramount number of groups/associations, from little to tremendous ones. Generally, these services are maintained with payment processors like Authorize.net, CheckOut, PayPal, or Linkpoint to ensure that the trades are secure, speedy and trustworthy, giving the key establishment and individual security. Similarly terms like Service, e-Service and Web Service are regularly brought into play to recognize a self-administering programming part that is especially perceived by a uniform resource identifier (URI), got to by standard Internet protocols, for instance, HTTP, XML or SOAP [J. Cardoso et al]. Web Services contrast with communication through the Internet. It supports Enterprise Application Integration (EAI), which implies compromise among applications or interoperability among the information which courses or circulates in an organization, as electronic exchange/commerce with clients and suppliers. In the present day, these services grant fuse between various systems like AIS, web applications and operational systems. Ultimately, they overhaul external and real time reporting, frequently growing information availability to a more broad extent of accomplices, with pretty much fulltime openness. It is expectable that budgetary accounting so as to account information enhances financial execution hostile decision and liquidity jeopardy [R. Bushmanet al]. Creditors and investors getting to incredible cash related accounting information are more instructed accomplices and, along these lines, have inferior risk of disaster or liquidity. Publicly or Exchanged on an open business sector relationship when in doubt need to make use of online reporting of cash related data. Other than this, associations similarly utilize their Web sites to put their budgetary enunciations and other money related reports [J. A. Hall 2010]. Gigantic bit of this effort of external reporting is associated with the progressive consistence. Some of these web services should license outside components to guarantee that the association is taking after all the key principles and set of laws. Other than the use of Web as a static compartment of cash related information, there is a continued with improvement of electronic and web-enabled accounting software services. These offers fuse web services and web support around accounting [Axia Consulting].

\section{B. PDAs (Mobile Services)}

This technology uprising, gave by method for wireless technologies, passes on astounding changes to improvement. It affects various viewpoints in business is driven, giving enormous data ceaselessly and wherever to offer pioneers, some assistance with affecting communications amidst associations and their customers, and changing the way we encounter our lives. Yet, the mobile services in like manner encounter defies which join business systems, endeavor peril, obstructions in mobile phones, networking issues, establishment objectives, security concerns, and customer uncertainty in mobile applications [K. Siau et al]. According to a survey guided by Oracle to more than 3,000 cell phone customers around the world, regardless of the way that clients like to purchase in store, they bring into play versatile and distinctive stations to reinforce shopping experiences. Also, 24 percent of adaptable customers have scrutinized customer overviews on their cell phone and 55 percent said they bring into play or might require using dealing with record/store applications on their cell phone and tablet PC [Oracle]. This slant reveals the essentialness of the mobile-commerce to services, accordingly the criticalness of organizing these structures and their execution data with the accounting information system. It moreover highlights the noteworthiness of business company's exercising versatile channels to make possible continuous reporting, supporting correspondence with their present and potential money related pros, fiscal, creditors or regulatory influence, extending the information availability to a more broad extent of accomplices and in this way the interest in the association. These days, there are business learning (BI) courses of action, like the Mobile-BI product from MicroStrategy [MicroStrategy], which bestows business examination and reports on tablets and on cell phones, allowing personnel's to take after their association execution.

\section{Cloud Computing (CC)}

Cloud Computing (CC) is promising as the next generation platform which would make possible the user on pay as you use mode as per condition. It endows with a number of paybacks which could not otherwise be realized. The main endeavor of cloud computing is to endow with a proficient 
access to remote and geographically distributed resources. With the spread of electronic systems, it is more fundamental to have web accounting software, reducing of independently on-premise or in-house accounting software. The imaginative answer may range between an encouraged course of action, a mixed online and on-premise game plan or a totally onlineaccounting software, with an answer in perspective of the cloud, which infers an architecture considering Software-as-aService (SaaS), generally called Cloud Computing (CC) [Axia Consulting]. Instead of on-premise application, running on an off-premises server, yet not unyieldingly managed by the application supplier, SaaS customer is running the same event of the AIS devoid of, clearly, surrender the versatility. In the present day, an application can run essentially more instances meanwhile, in a run of the mill circumstance, on account of innovative software design and transport models. McKinsey 2006 investigation of senior IT authorities showed an extraordinary jump in the amount of associations considering SaaS applications in the midst of 2007. SaaS offers a couple purposes of enthusiasm, as more unending and likely less disquieting redesigns, a lower cost of proprietorship, and a more raised measure of service from suppliers [A. Dubey et al]. With this sort of plan, unmistakable sort of accomplices/stakeholders can access to solid accounting and back organization (finance management) functionalities with concurrent reporting from wherever there's a web affiliation. Such as Intacct Financials and Accounting System, NetSuite Financials, Microsoft Dynamics GP, Epicor Financial Management, SAGE or SAP ERP Financials.

\section{Environmental Scanning}

It can be portrayed as the getting and usage of information about tendencies, events, and associations in an organization or business group outside surroundings, the data of which would help administration in masterminding the organization's future procedure [MicroStrategy]. Organization still nonchalance outside information. Yet, it stays crucial to take fundamental decisions. Thusly, it is basic to make systems which can look for outside information that can be brought into play to facilitate organization or business group. For instance, bona fide costs have handiness, yet they are deficient for the evaluation of business decisions. The point of convergence of thought of routine accounting on the stewardship limit of accounting is basic yet should not be its simply focal point [A. Dubey et al]. An additional cost viewpoint is the at hand outlay. It identifies with the quality that must be compensated for favorable position or its usage at the date of the financial record or the date of the exercise. A couple of specialists are inclined to join evident and stream schedules. Though hard to execute, current cost accounting increments with ES. The ES fabricates a more complete viewpoint. Its capacities support essential examination process or strategic analysis by propelling the data about crucial outside points of view. It moreover allows benchmarking by expanding all the additionally understanding about the business segment and contenders. In addition, some external information, like present or future expenses of things or advance expenses (Interest), may anticipate slants or perceive and manage a couple of perils.

\section{E. Business Intelligence (BI)}

Strategic Management (SM) bestows by and large a beeline or route to the venture. Yet, remembering the finished objective to have the ability to reinforce and affirm their fundamental objective, vision and targets, organizations should have to weigh up the general execution of the business and its empowering towards destinations. By dealing with a great deal of information, the Business Intelligence recognizes and develops innovative open entryways. Moreover, BI helps organization at an imperative level, and also at a key and operational level, giving significant bits of learning which beat decisions inventors and in addition middle managers, offering tailor-made dashboards. BI every now and again attracts systems like data mining, strategy mining, quantifiable examination, or predictive modeling or insightful examination which can support some management accounting concerns like evaluating, or some management uphold concerns, for example, recognizing and separating key decisions, decision backing, strategic management accounting or business risk management. The preceding Computerworld's audit about pay exhibited that prospect selection will give need not simply to routine IT aptitudes like application change or offer work territory some help with supporting, moreover to some more innovative capacities, for instance, BI, mobile development and cloud computing [C. W. Choo]. Starting late, another term has risen named as accounting intelligence (AI). The accounting information is an ace kind of business understanding, an expression significance a plan of developments brought into play to focus, look at and show information from ERP and accounting applications. One basic qualification between built up AI game plans and BI is emerging information is isolated. At AI, information is particularly expelled from the ERP at the time that a request is run. Regardless of what may be normal, set up BI courses of action separate information through a data dispersion focus or OLAP strong shape. SAGE bestows consistent information by granting a captivating course of action called Sage Simply Accounting Intelligence which interfaces particularly to Sage Simply Accounting system [N. B. A. Bakar et al].

\section{F. The Enterprise Architecture \& its Application Integration}

The obtainment of an extensive viewpoint of the endeavor/enterprise is the most indispensable facet of the architecture of an enterprise. This privileged systems coordination unites information from prior irregular areas [B. Stackpole et al]. Among others perspectives, the enterprise architecture should give a coordination framework that sits over the individual architectures and the standards to describe and develop interoperability necessities [M. Lankhorst]. Generally, the setup of enterprise architecture unequivocally depends on upon the compromise of diverse applications so that they may share information and processes uninhibitedly. This is typically called by the popular expression Enterprise Application Integration [T. The Open Group]. Interoperability characteristics, that is to say, "the ability to share information and services", grants AIS be more planned or introduced with distinctive structures, and in this way, be all the more convincing. The eXtensible Business Reporting Language (XBRL), a XML-based scripting/programming language, is a transparently open and overall standard for exchanging business information, permitting the expression ordinarily mandatory in business reporting. An organized and multifaceted basic designing or architecture facilitates a bit of the presented accounting defies like benchmarking, risk management, forecasting, strategic analysis, internal auditing, real time reporting, internal controls and the blend of more non-budgetary data. Case in point, most business organizations contain cash related reporting as a batch process, due to its intermittent character. Then again, different organizations have now real-time updating of financial 
reporting system (FRS) and general record (GL) conveying budgetary verbalizations simply under the wire [J. Cardoso et al]. Nonstop or real-time reporting capacity of structures or systems depends on upon the level of its consolidation. Speculatively, the more applications are fused, speedier the reporting ought to be conceivable. Enterprise Resource Planning (ERP) systems as a general rule take part in the privileged endeavor to facilitate or integrate. Yet, ERP don't reinforce significatively the reporting and scrutiny, noncash/financial related, external and off the cuff (ad-hoc) management accounting, and cost provision. Strategic enterprise management (SEM) systems seems to better reinforce management accounting, specifically changes among those practices. SEM \& ERP systems are correlative. ERP systems appear, from every angle, to be the fundamental engaging impacts of advancement in data collection and various leveled extensiveness of management accounting, while SEM systems have all the earmarks of being the crucial enabling operators of advancement in budgeting, reporting and analysis, non-financial associated, external and off the cuff management accounting, and costs provision [J. Varajão et al]. Pertaining to management accounting errands, disregarding the way that SEM and ERP systems are specific, it is critical strengthen the way which drove relationship to bigger measures of information compromise among those two systems and in addition with others. A key try to have an overall point of view is the Corporate Performance Management (CPM) system. Business performance management or undertaking execution organization (EPM) or CPM is the zone of business intelligence (BI) included with checking and managing the performance of an organization as demonstrated by key performance indicators (KPIs) like revenue, return on investment (ROI), overhead or operational costs. A higher blend redesigns reporting with vacillated sorts of data, controlling new limits and capacities. The thorough viewpoint gave by enterprise application integration and try auxiliary designing moreover facilitates an unrivaled strategic analysis or imperative examination.

\section{G. Business Process Management (BPM)}

Huge topical exercises, like Six Sigma, Enterprise Resource Planning (ERP), Customer Relationship Management (CRM), and all the more starting late Business Process Management (BPM) insinuate system has a basic and central thought. Research about enterprise resource planning essential segments of accomplishment and points of interest, demonstrate that, from a business point of view, the system association stage 'comprises the importance of the documentation, analysis, change, control and reengineering possibilities of all the most fundamental processes and focus practices [M. Al-Mashari et al]. Processes are a common aspect along all organizations. Processes are the way things complete [C. Armistead et al]. A couple of researchers spotlights on the hugeness of processes calling them key or strategic assets. For example, [R. S. Kaplan et al] suggest a Strategy Map, with tricky assets which effect association's execution by enhancing the internal processes most essential in making quality for shareholders and customers [R. S. Kaplan et al]. Awesome decisions must have information as complete as could be normal the situation being what it is. Preferably, imperative bits of information should be consolidated to propel the reporting, including unmistakable sort of data, like specific execution data starting from work procedure of each basic process [J. Cardoso et al]. The processes dematerialization permits that Business Process
Management better sponsorship the movement of non-cash or non-financial related data to AIS's. Whether at an operational level, or at key level, the organization of strategies furthermore administrates pointers of execution and of diverse sorts. Created process applications totally express Processes, with suppliers and customers being seen as a part of the organization [H. Smith et al]. Production, material or other human costs or execution pointers/indicators of the process can be administered at a lower or at a bigger sum. Business Process Management, with its work process functionality in like way fused within AIS, supports the analytic accounting and real-time reporting in light of the way that it allows a bare essential analysis of processes therefore facilitates the quick division of revenue and costs to explicit revenue or outlay hub.

G. Computer Assisted Auditing Tools and Techniques (CAATTs)

Evaluators or Auditors need CAATTs to boost limits and gainfulness. Various such gadgets and systems can be realized at insignificant cost and relative effortlessness, running from enhanced usage of standard office suite software to Audit Command Language (ACL) and Interactive Data Extraction and Analysis (IDEA) for the data extraction and analysis [D. Coderre]. These gadgets/tools can be brought into play to perform a broad assortment of exploratory strategy on distinctive fiscal data including general record entries, back and records payable data and trial balance estimations to pennant peculiarities, mistaken conclusions, or suspicious areas that may demonstrate the region of misrepresent or fraud [A. I. o. C. P. A. AICPA]. These instruments permit the execution of continuous auditing concept, which allows constant risk assessment, trough survey practices that perceive and survey companywide risk levels by taking a gander at examples in the data driven risk indicators within a solitary process or system, diverging from their past execution and diverse business structures; and predictable control evaluation that recognize whether key controls are functioning genuinely [D. Coderre].

\section{H. The Big Data}

The big data systems perspective is supported by scale, parallelization, and deftness, using diverse machines working as a piece of parallel to store and process data. Marvelous associations or business groups reliably make generous measure of data. Corporate business manages a couple of associations or businesses. Accounting and cash related information from these assorted associations over the world join colossal non-budgetary data. Yet, today, businesses or trades from all estimations have a tendency to convey significantly more data than they made already. According to Phil Ostwalt, an assistant in KPMG, as more business activities are gotten electronically, ensure that business groups have the right advancement and resources for deal with data examination and immense data defies trademark in all consistence domains [D. Coderre]. Risk management, internal controls and internal auditing are domains where the colossal data may identify with a basic answer. This great measure of data passes on novel and specific new-fangled troubles to most architects. Colossal data frameworks are key to answer these defies.

\section{SUMMARY}

The accounting industry is currently speaking a brand new language of business. It is the language of prospect 
generations of accounting professionals. The fruition of accounting technology has been marvelous with strapping expansion probable for the prospect. The progressions have taken the industry to lots of innovative levels of opportunities that have outlined throughout this article. In comparing and contrasting the changes that have taken place with the exercise of technology in accounting all the way through the ages, enterprise efficiency has fashioned profession solidity and numerous miscellaneous opportunities in this flourishing industry of professional accountants. We outlined the stresses and troubles in the area of Accounting to which the response from the present advancement is still lacking. Development elucidations recognized and depicted here can in like manner be seen as the future course of examination in this particular area of accounting. The boundless headings appeared in Figure 1 of this article, which shows the nearly all crucial relations between the defies and creative responses, are demonstrating out the way for future investigation all together upgrade the game plan amidst advancement and organization.

\section{REFERENCES}

[1] "H. Smith et al", Business Process Management: the third wave: Meghan-Kiffer Press, 2002.

[2] "J. L. Colbert", "Corporate governance: communications from internal and external auditors," Managerial Auditing Journal, vol. 17, pp. 147-152, 2002.

[3] "M. G. Alles et al", "Exploiting comparative advantage: A paradigm for value added research in accounting information systems," International Journal of Accounting Information Systems, vol. 9, pp. 202-215, $12 / / 2008$.

[4] "Oracle", "Opportunity Calling: The Future of Mobile Communications," ed: Oracle, 2011.

[5] "A. Trigo et al", "Enterprise Information Systems Adoption in Iberian Large Companies: Motivations and Trends," in Managing Adaptability, Intervention, and People in Enterprise Information Systems, M. Tavana, Ed., ed, 2011.

[6] "A. Rom et al", "Enterprise resource planning systems, strategic enterprise management systems and management accounting: a Danish study," Journal of Enterprise Information Management, vol. 19, pp. 50-66, 2006.

[7] "N. V. d. Almeida et al", "Open source workflow management systems for the internal audit process," presented at the Proceedings of the Workshop on Open Source and Design of Communication, Lisboa, Portugal, 2012.

[8] [8] "R. R. Moeller", COSO Enterprise Risk Management: Establishing Effective Governance, Risk, and Compliance Processes, Second Edition: John Wiley \& Sons, 2011.

[9] "S. V. Grabski et al", "A Review of ERP Research: A Future Agenda for Accounting Information Systems," Journal of Information Systems, vol. 25, pp. 37-78, 2011/03/01 2011.

[10] "E. U. Grande et al", "The impact of Accounting Information Systems (AIS) on performance measures: empirical evidence in Spanish SMEs," The International
Journal of Digital Accounting Research, vol. 11, pp. 25 46, 2011.

[11] "J. Cardoso et al", "Service engineering for the internet of services," in ENTERprise Information Systems, ed: Springer, 2009, pp. 15-27.

[12] "J. Luftman", "Assessing IT/Business Alignment," Information Systems Management, vol. 20, pp. 9-15, 2003.

[13] "R. Bushmanet al", "Transparency, financial accounting information, and corporate governance," Financial Accounting Information, and Corporate Governance. Economic Policy Review, vol. 9, 2003.

[14] "A. Anandarajan et al", "Historical Overview of Accounting Information Systems," in Business Intelligence Techniques, 2004, pp. 1-19.

[15] "J. Varajão et al", "Motivations and Trends for IT/IS Adoption: Insights from Portuguese Companies," International Journal of Enterprise Information Systems (IJEIS), vol. 5, pp. 34-52, 2009.

[16] "N. A. Ismail", "Firm performance and AIS alignment in Malaysian SMEs," International Journal of Accounting Information Systems, vol. 6, pp. 241-259, 12, 2005.

[17] “M. D. Mayberry”, 2013, CAATTs Ideal for Efficient Audits.

[18] "R. B. Cooper", "Review of management information systems research: A management support emphasis," Information Processing \& Management, vol. 24, pp. 73102, // 1988.

[19] "R. S. Poston et al", "Accounting information systems research: Is it another QWERTY?," International Journal of Accounting Information Systems, vol. 1, pp. 9$53,3,2000$

[20] “A. Fontinelle", (2011, 2013, Apr 5). Introduction To Accounting Information Systems. Available: http://www.investopedia.com/articles/professionaleducati on/11/accounting-information-systems.asp

[21] "J. A. Hall", Accounting Information Systems: South Western Educational Publishing, 2010.

[22] "A. Rom et al", "Management accounting and integrated information systems: A literature review," International Journal of Accounting Information Systems, vol. 8, pp. 40-68, 3// 2007.

[23] "R. S. Kaplan et al", "Measuring the strategic readiness of intangible assets," Harvard Business Review, vol. 82, pp. 52- 63, Feb 2004.

[24] "J. A. Hall", "Financial Reporting and Management Reporting Systems," in Accounting Information Systems, J. A. Hall, Ed., $7^{\text {th }}$ Edition ed: Cengage Learning, 2010, pp. 349-393.

[25] "Axia Consulting", (2013, 2013, 12 Apr). Accounting Software: Current trends.

[26] "W. Van der Stede et al", "Accounting trends in a borderless world," Chartered Institute of Management Accountants 1859716903, 2010. 
[27] "K. Siau et al", "Mobile communications and mobile services," International Journal of Mobile Communications, vol. 1, pp. 3-14, 2003.

[28] "MicroStrategy", "MicroStrategy Mobile App Platform," ed, 2012.

[29] "A. Dubey et al”, "Delivering software as a service," The McKinsey Quarterly, vol. 6, pp. 1-12, 2007.

[30] "D. Coderre", Internal Audit: Eficiency though automation: The Institute of Internal Auditors, 2009.

[31] “A. I. o. C. P. A. AICPA”, (2013, Frequently Asked Questions: Computer Assisted Auditing Tools and Techniques (CAATTs)

[32] "Fernando Belfo et al", "Accounting Information Systems: Tradition and Future Directions", CENTERIS 2013

[33] "C. W. Choo", "Environmental scanning as information seeking and organizational learning," Information Research, vol. 7, pp. 7-1, 2001.

[34] "N. B. A. Bakar et al", "Historical Cost Versus Current Cost Accounting," Accountants Today, pp. 20-23, 2007.

[35] "B. Stackpole et al", "Computerworld IT Salary Survey 2013, 27th Annual Survey," Computerworld, April 08, 2013.
[36] "M. Lankhorst", Enterprise architecture at work: Modelling, communication and analysis: Springer, 2013.

[37] "T. The Open Group", "The Open Group Architecture Framework (TOGAF) Version 9," ed: The Open Group, 2009.

[38] "M. Al-Mashari et al", "Enterprise resource planning: a taxonomy of critical factors," European Journal of Operational Research, vol. 146, pp. 352-364, 16 April, 2003.

[39] "C. Armistead et al", "Strategic business process management for organisational effectiveness," Long Range Planning, vol. 32, pp. 96-106, 19 March , 1999.

[40] "F. Belfo", "A framework to enhance business and IT alignment through incentive policy," International Journal of Information Systems in the Service Sector (IJISSS), vol. 5, pp. 1-16, April-June 2013.

[41] "F. P. Belfo", "Workforce Incentives at IT companies: the Google's Case," IADIS International Journal on WWW Internet, vol. 9, pp. 69-84, 2011

[42] "F. Belfo", "The Role of Knowledge Management in the Strategic Alignment of Information Technology with Business: A Graphical and Systemic view," in 11th European Conference on Knowledge Management, Famalicão, Portugal, 2010, pp. 1129-1137. 